\title{
Swimming against the tide
}

\author{
Eric Ashby
}

The Politics of Self-Sufficiency. By Michael Allaby and Peter Bunyard. Pp.242. (Oxford University Press: 1980.) Hbk £7.95, \$24.95; pbk £3.95.

If you see someone swimming against the tide, watch him. He may sink without trace; he may bring ashore a new idea. It is in this spirit that I commend this duet by Michael Allaby and Peter Bunyard. A duet? Yes, for in each chapter first one author, then the other, has his say. The two authors agree in principle that selfsufficiency in a Good Thing. They do not agree about the way in which selfsufficiency might be achieved nor about the part it might play in Western industrial society.

On the first page the authors define what they are writing about. It is not the selfsufficiency of pioneers colonizing a hostile environment, often by a ruthless exploitation of nature; it is self-sufficiency as an alternative "lifestyle": the community which grows its own food (preferably without artificial manures), generates its own energy (or some of it) from sunlight and the burning of timber, disposes of its own wastes, imports such things as it cannot make in exchange for its own surplus, by barter, not money. There are already little communities of this kind in Britain, and the Israeli kibbutz and Chinese commune are viable versions of a similar idea. Indeed, if one is looking for historical precedents for self-sufficiency, the mediaeval monastery is surely an impressive example.

The self-sufficient community, like the monastic community, can be sustained as a minority way of life in an industrial pluralistic democracy. It is when enthusiasts for self-sufficiency urge us to make it a majority way of life that doubts arise. All sorts of awkward questions have to be answered. Is it, in any case, a "better" lifestyle? Could such a lifestyle be sustained by the minorities who enjoy it if they were not embedded in a conventional capitalist society which can come to their rescue when they need to travel, to listen to music, to get medical attention, to type and publish books such as this one, to replace tools? And, since this is a book about the politics of self-sufficiency, under what kind of political system could selfsufficiency ever become a majority lifestyle?

The virtue of the book is that it does examine these questions honestly. It considers the prospects for a massmovement toward self-sufficiency. The

\section{IMAGE \\ UNAVAILABLE \\ FOR COPYRIGHT REASONS}

Self-sufficiency in the Middle Ages - how viable today?

prophets have to step warily between the ideologies of anarchy on one side and fascism on the other. Except for hermits, self-sufficiency implies co-operation, and "the moment a group of people act collectively they cease to act anarchically". So the self-sufficient society would have to submit itself to some sort of government. If it is to be a government which rejects an economic system based on motives of profit, then "the economy itself would be changed from a market to a command type. The injunction to industrialists would no longer be the simple 'Be profitable!' but the much more complex 'Make this, but not that'." The only known patterns of government capable of behaving this way are far-left or far-right dictatorships. The authors don't relish either of these. They seek a middle way: some communal ownership of property; some concession to the fact (which they freely admit) that an atavistic retreat to a bucolic past is simply not on; some compromise with the harsh reality of the human condition, which is that greed, selfishness and love of comfort are majority attitudes, and that beneficence, self-denial and austerity are likely to remain minority attitudes. They adduce plenty of evidence that small communities can - and some do drastically reduce their reliance upon the products of industrial society, and consume much less per capita than the average consumption of the limited resources of nature. They make the point clearly that they do not consider selfsufficiency to be a middle class élitist indulgence or a highbrow name for dropouts. Self-sufficiency is a deep - they call it a "spiritual" - protest against a way of life which is carrying us out on a tidal current to God knows what dangers.

Anyone who seriously contemplates selfsufficiency in political terms had better stand at Waterloo Station in the rush hour and ask himself exactly how any political movement is going to lead this surge of commuters into such a different lifestyle, and ensure that they are adequately fed, sheltered and kept warm in (say) the idyllic conditions of rural Devon and Cornwall. (And, incidentally, ask himself what would happen to Devon and Cornwall if such a miracle occurred.) But this would be a slick and insensitive way to end this review: for there is one important conclusion to be drawn from this book, though it may not be a conclusion the authors approve. It is that little self-sufficient communities such as Allaby and Bunyard describe have an important part to play in contemporary Britain. Like monasteries in the Dark Ages, they affirm that there is another, and perhaps a better, way to live than the way most people live and that it is not out of reach. They are not composed of cranks. They are men and women who believe in swimming against the tide. They may sink without trace. But, like monasteries in the Dark Ages, they may carry the seeds for a new kind of civilization, one able to transform the taint of unemployment into the boon of leisure for those without work, and the drudgery of attending an assembly line for the satisfaction of manual labour for those who have work.

Lord Ashby is Chancellor of Queen's University, Belfast, and a Fellow of Clare College, Cambridge. 